\title{
The Significance of Propagating Islam Hadhari in Japan
}

\author{
Kazunori Hamamoto*
}

More than a year has passed since Tun Abdullah Ahmad Badawi resigned his position as Prime Minister of Malaysia. His Islam Hadhari (Civilisational Islam) approach is no longer a journalistic topic. However, I believe it is still significant as a topic of contemporary Islamic thought for it faces up to such serious problems as poverty and violence throughout the Muslim world of today and seeks well-balanced solutions which are not only consistent with Islamic ethics and moral values but also compatible with modernisation and multicultural realities. This Viewpoint proposes that the ideas of Islam Hadhari should be introduced to the Japanese people in order to correct their often distorted image of Islam. First, I shall report on how Islam is misunderstood by many of them, quoting eminent Japanese writers and politicians; then I shall refer to the efforts that should be made to improve the situation. I shall conclude by suggesting that propagating Islam Hadhari in Japan would help Japanese people understand Islam better.

\section{Misunderstandings of Islam among the Japanese People}

Various epithets such as 'violent' and 'anachronistic' have been unjustly given to Islam in Japan as well as in the West. Among others, 'monistic' and 'exclusive' are noteworthy sobriquets for Islam for those coming from the Japanese polytheistic tradition. An emeritus professor at Tokyo University, Takeshi Yoro, criticises monotheism for its monistic way of thinking, insisting that the monotheistic assumption that "I am 100\% right" causes wars, terrorism and conflicts between nations or religions. ${ }^{1}$ Although his distorted view on monotheism is too simplistic in that he ignores, for instance, studies on diversity and pluralism by Muslims, such views are quite popular in Japan. In fact, Bakano kabe (Barriers Surrounding Bigoted Minds) - the book in which he expressed this view - topped the bestseller list in Japan in 2003. In June 2004, the Democratic Party proposed, in an interim report on amending the Constitution, that Japan should build a tolerant multicultural society based on Japanese polytheistic values, thereby totally disregarding monotheistic approaches. In November 2009, Ichiro Ozawa, Secretary-General of the Democratic Party, even remarked that "Christianity and Islam are exclusive". 2

In order to counter such misperceptions, Higuchi Mimasaka, emeritus chairman of the Japan Muslim Association, has expressed his hope that not only non-Muslims * Kazunori Hamamoto is a PhD candidate at the Graduate School of Theology, Doshisha University,
Kyoto, Japan. 
but also Muslims themselves in Japan will learn more about Islam. In the preface of his book, he says that two motives had urged him to write it: his sorrow for the Japanese people's misconception of Islam as a militant religion and his concern over those Japanese Muslims who find it difficult to live up to Islamic values and standards in Japan. As for the second motive, he seems to be more anxious about those who are ready to 'exit' from Japanese society, supposedly on behalf of Islam, than about those who tend to neglect Muslim duties. Referring to a young Japanese Muslim who quit his job because he was not allowed to grow a beard at his workplace, Higuchi deplores this man for "mistaking Islam for having a particular appearance or leading a reticent and isolated life". ${ }^{3}$

\section{What Efforts Should Be Made?}

Above all, it should be made clear that Islam is a peaceful religion. However, such a statement might sound empty without serious attempts to eradicate acts of terrorism. Muslims must stop killing innocent civilians and infighting.

Second, concerning the accusation that Islam is monistic and exclusive, it should be explained that various interpretations of the Revelation have coexisted all the time since the Prophet Muhammad died and that the Qur'ān has numerous verses which are favourable to religious pluralism. ${ }^{4}$

Third, with regard to the view that Islam is anachronistic, it should be pointed out that this view is based on the prevailing values in the contemporary world namely Western values. Therefore, if someone oppresses Muslims merely because their faith seems not accord with today's dominant values, he should be blamed for his own monism and exclusivism. It should be noted, on the other hand, that Islam does not refuse dialogue with religions nor does Islam deny that interpretations of the Revelation may vary, depending on matters of time, place, and particular circumstances. This implies that Islam does have the ability to reach consensus with other religions through meaningful dialogue between them.

Fourth, it should be taught that God does not want to burden people with hardship. Accordingly, a conversion to Islam does not demand to change one's lifestyle totally, let alone to break away from one's society. Conceding that it is not easy to pray five times a day and fast for a full month every year in Japanese industrious culture, still Higuchi Mimasaka maintains, from his experience of Muslim life for over forty years, that Japanese Muslims should try to get along with Japanese society. He admits that Muslims have to be flexible in Japan. Instead, he emphasises the importance of penitence and compensation for not fulfilling duties, referring to the Prophet Muhammad's explanation that every good deed is acceptable as atonement - for example, removing stones, thorns and bones from roads or offering words and deeds of kindness to others. Furthermore, Higuchi observes that many Islamic 
virtues, such as charity, love for neighbours, honesty, tolerance and moderation, are actually also Japanese traditional virtues. Therefore, he concludes, "if Muslims in Japan bear this in mind and lead a peaceful and well-balanced life, they can propagate Islam without even raising their voices". ${ }^{5}$

\section{The Merits of Islam Hadhari}

Despite its emphasis on economic development, Islam Hadhari should not be rashly judged as caring only about worldly matters. This is because the first principle of Islam Hadhari - faith and piety in Allāh - requires Muslims to practise Islam wholesomely. ${ }^{6}$ In this respect, there is no difference between 'traditional Islam' and Islam Hadhari.

It was not with the intention of 'distorting' or 'reducing' Islam that Tun Abdullah Badawi emphasised economic development; he focused on what today's Muslims, especially the Malays, often tend to neglect - for, generally speaking, administrative leaders should prioritise urgent concerns in order to make the most of their limited time and resources. In other words, Abdullah chooses to tackle economic problems first so that Islamic civilisation can recover its completeness and soundness. As he affirms, "It is an effort to bring the ummah back to the basics of Islam. [...] it will not cause Muslims to deviate from the true path."

Some readers might ask what on earth Japanese people, who have been called 'economic animals', can learn from Islam Hadhari. However, civilisation is not a mere accumulation of its material components. ${ }^{8}$ Whoever reads some of the speeches which Abdullah gave on Islam Hadhari will notice that he repeatedly emphasised the importance of spiritual elements, such as honesty, integrity, fraternity, charity, passion for justice, sense of fairness, love for peace, tolerance of diversity, willingness to dialogue, moderation, openness to self-criticism, and eagerness for knowledge. In Japan, as I wrote above, some of these have been regarded as alien to Islam, and this regrettable misunderstanding has prevented Japanese people from understand Islam properly. If they learn more about Islam Hadhari, they will be more sympathetic, or less hostile, to Islam.

Abdullah encouraged Muslims not only to be morally upright but also to promote intellectual reform through ijtihād (intellectual effort) and jihād (practical effort), being convinced that the currently prevailing miserable situation of the contemporary Muslim world is attributable to blind imitation (taqlīd) of traditional views. Ijtihād makes interpretations of the Revelation suited to time and conditions. As for $j i h \bar{a} d$, Abdullah, going back to its original and undistorted meaning, proposes that it should be interpreted as struggle in all aspects of life, including the pursuit of knowledge and the mastery of science. ${ }^{9}$ If these efforts toward civilisational renewal could be 
made known to the Japanese people, their misconception that Islam is rigid and out-of-date could be modified.

Admittedly, Islam Hadhari does not answer directly the question of how Japanese Muslims should live. However, Abdullah's call for ijtihād would enable them to understand the flexibility of Islam. They would also come to appreciate the importance of a proper balance between so-called 'religious matters' and so-called 'worldly matters' from Abdullah's emphasis on 'moderation' and his belief that God not merely imposes ritual duties but requires Muslims to make every endeavour toward civilisational development. Furthermore, they would ultimately realise that Japanese Muslims have an obligation of dialogue with non-Muslims in Japan and that if they do make efforts for this purpose, it would be a great contribution to the development of Islamic civilisation.

\section{Notes}

1. Yoro Takashi, Bakano kabe (Tokyo: Shinchosha, 2003), 20-1 and 30.

2. http://www.asahi.com/politics/update/1110/TKY200911100459.html, accessed on 19 March 2010 [in Japanese].

3. Higuchi Mimasaka, Nihonjinmusurimutoshite ikiru (Tokyo: Kouseishuppansha, Tokyo, 2007), 5 and 229-30.

4. Religious pluralism in Islam is different from that in the West; see Mohammad Hashim Kamali, "Diversity and Pluralism: A Qur'ānic Perspective", Islam and Civilisational Renewal 1, no. 1 (October 2009), 34-5.

5. Higuchi Mimasaka, Nihonjinmusurimutoshite ikiru, 234-6 and 244-5.

6. Mohammad Hashim Kamali, Civilisational Renewal: Revisiting the Islam Hadhari Approach (Kuala Lumpur: IAIS Malaysia, 2008), 15.

7. Abdullah Ahmad Badawi, Islam Hadhari: A Model Approach for Development and Progress (Kuala Lumpur: MPH, 2006), 3.

8. Malik Bennabi, Mushkilāt al-afkār fì 'l- 'àlam al-islāmī (Cairo: Maktabah 'Ammān, 1971), 50, quoted in Kamali, Civilisational Renewal, 26-7.

9. Abdullah, Islam Hadhari, 68. 